\title{
Electronic cigarettes: Genetic and epigenetic impact (Review)
}

\author{
NICOLÁS NIEDERBACHER ${ }^{1}$, LITZY GISELLA BERMUDEZ ${ }^{1}$, DANIEL MAURICIO GONZÁLEZ ${ }^{1}$, \\ CAMILA BERNAL ${ }^{1}$, FRANCISCO GARCÍA ${ }^{1}$, DANIEL LEÓN ${ }^{1}$, MARIA JOSE PINZÓN ${ }^{1}$, \\ CARLOS CAMERO $^{1}$, ITHZAYANA MADARIAGA ${ }^{1}$, PAULA SÁNCHEZ ${ }^{1}$, ANDREA RODRÍGUEZ ${ }^{1}$, \\ SALIME HURTADO $^{1}$, CATHERINE TOVAR ${ }^{1}$, SANTIAGO RODRÍGUEZ-ARIZA ${ }^{1}$, \\ RAFAEL CASTRO $^{1}$, MARIANA GUERRA ${ }^{1}$, ALEJANDRA CAÑAS ${ }^{1,2}$ and ADRIANA ROJAS ${ }^{1,3}$ \\ ${ }^{1}$ Epigenetics and Cancer Research Group, Institute of Human Genetics, Pontificia Universidad Javeriana; \\ ${ }^{2}$ Department of Internal Medicine, Faculty of Medicine, Pontificia Universidad Javeriana; ${ }^{3}$ Institute of Human Genetics, \\ Faculty of Medicine, Pontificia Universidad Javeriana, Bogotá 110231, Colombia
}

Received November 21, 2020; Accepted January 14, 2021

DOI: $10.3892 / \mathrm{ije} .2021 .2$

\begin{abstract}
Electronic cigarettes (ECIGs) are electronic devices that heat and vaporize a solution that usually contains a mixture of glycerol, propylene glycol, water, flavors and various concentrations of nicotine. ECIGs have 3 key components: A power source, a cartridge containing an atomizer along with a liquid solution and a mouthpiece. The solution (often known as e-liquid or e-juice) is heated into an aerosol inhaled by the user. Smoking conventional cigarettes is considered a determinant factor in the development of chronic respiratory diseases, cardiovascular diseases, cancers, and reproductive system dysfunctions. Conventional smoking also causes genome damage and alteration of the transcriptome, due to the amounts of noxious substances emitted during the combustion of these products. Recently, cigarette consumers have begun to use ECIGs as a replacement or substitute practice to help them quit smoking. In addition, an increase in the use of ECIGs and similar devices by young individuals has been reported, which is unsurprising due to the unregulated distribution and sale of these products. The present review article describes and discusses the impact and the noxious effects of substances in ECIGs and other nicotine administration systems on DNA structure, gene expression profile, and epigenetic modification, focusing on the respiratory system and embryonic development.
\end{abstract}

Correspondence to: Professor Adriana Rojas, Institute of Human Genetics, Faculty of Medicine, Pontificia Universidad Javeriana, Carrera 7, No. 40-62, Bogotá 110231, Colombia

E-mail: rojas-adriana@javeriana.edu.co

Abbreviations: ECIGs, electronic cigarettes; eCO, exhaled carbon monoxide; eNO, exhaled nitric oxide; FEF, forced expiratory flow; FEV, forced expiratory volume; HRCT, high-resolution computed tomography; $\mathrm{TcpO}_{2}$, transcutaneous oxygen tension

Key words: epigenetics, electronic nicotine delivery systems, vaping, adverse effects, e-cigarette vapor, gene expression, lung injury

\section{Contents}

1. Introduction to electronic cigarettes

2. ECIGs components, function and categories

3. Chemical compounds found in ECIGs

4. Noxious effects of ECIGs on DNA

5. Effect of ECIGs on genes involved in the immune response

6. Effect of ECIGs on genes involved in the circadian clock

7. Effects of ECIGs on the epigenome

8. Effects of nicotine administration systems on pulmonary function

9. Conclusion

\section{Introduction to electronic cigarettes}

Electronic cigarettes (ECIGs), also known as 'smokeless cigarettes,' 'e-hookahs,' 'vape pens' and 'vapes', are electronic devices that heat and vaporize a solution that usually contains a mixture of glycerol, propylene glycol, water, flavors and various nicotine concentrations (1). The first electronic cigarette patents date back to 1965 (2). The concept of this new product was a 'smokeless nontobacco cigarette', to provide 'a safe and harmless tool and method for smoking' (3). However, ECIGs were not commercially available until 2004. Since they have been marketed, they have become one of the products with the highest commercial growth rate (4).

\section{ECIGs components, function and categories}

ECIG devices have 3 key components: A power source, a cartridge containing an atomizer to heat a solution that typically contains nicotine and a mouthpiece. The liquid solution (often termed e-liquid or e-juice) that is stored in the cartridge, heats up in the device producing an aerosol inhaled by the user through the mouthpiece (Fig. 1) (5).

In the evolution of ECIGs, companies have used technology to improve devices. Four generations of ECIGs can be identified. The first generation, originally designed to imitate 

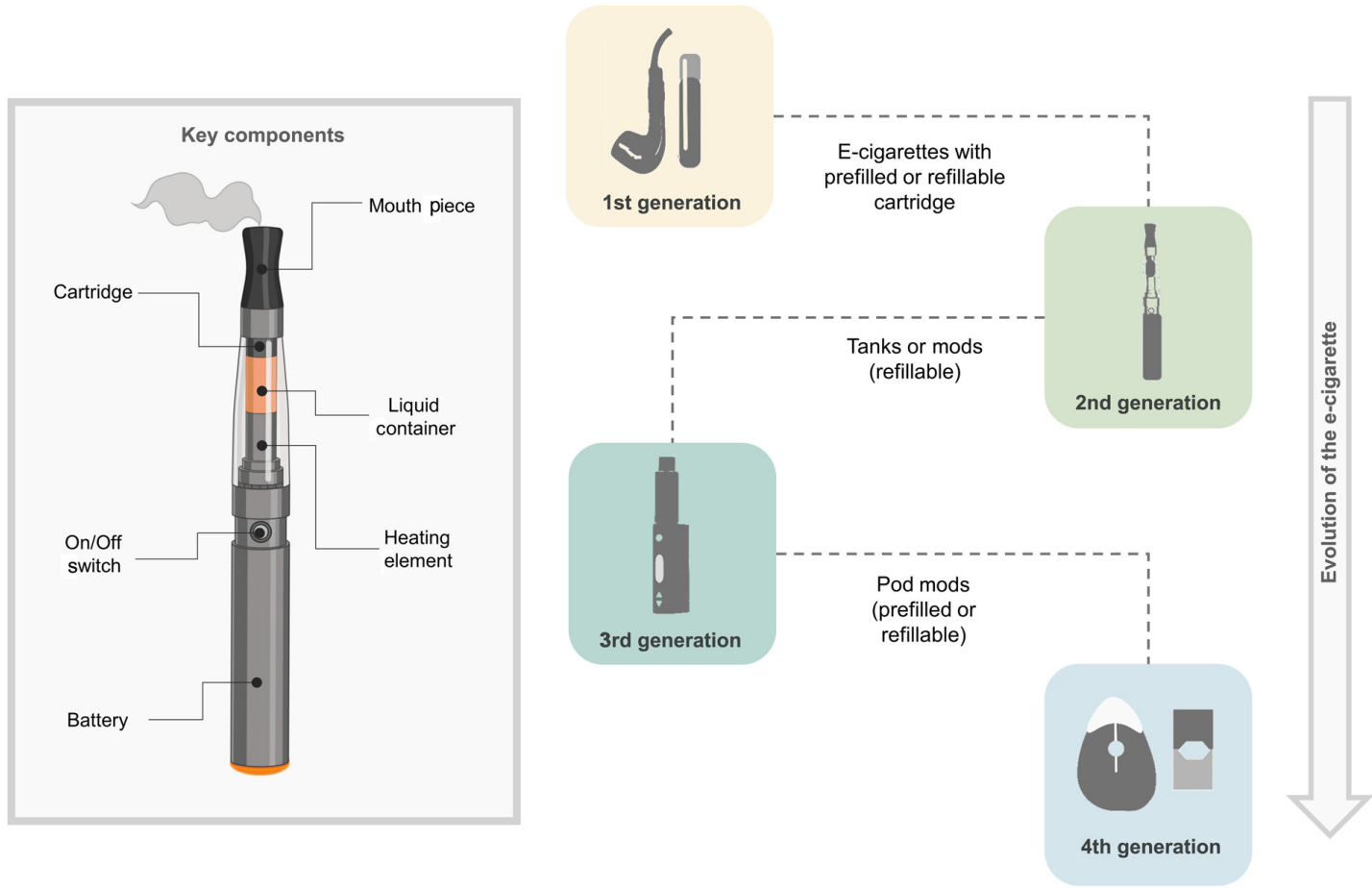

Figure 1. ECIGs: Evolution and components. Throughout the evolution of ECIGs, essential parts such as the mouthpiece, cartridge tank (holds the liquid juice), heating element, on/off switch, cartridge, and battery remain. The first generation are non-refillable devices designed for single use that mimic the appearance of traditional cigarettes. The second generation are rechargeable devices, with interchangeable substance cartridges and interchangeable battery spare parts. The third generation are modifiable devices ('mods') that allow users to customize the substances in the device with a tank that contributes to the generation of increased vapor and delivery of substances such as nicotine. Finally, fourth generation are compact capsule-like devices (Pod Mods) attached via magnets that demand less energy and generate more steam. Pod Mods typically use nicotine salts instead of the free-base nicotine used in most others ECIGs. The figure was modified from CDC, E-Cigarette, or Vaping, Products Visual Dictionary, 2019 (https://www.cdc.gov). Created with BioRender.com. ECIGs, electronic cigarettes.

the conventional cigarette in appearance, is also known as the young category, or Cig-a-like. It was built with a disposable filter, an integrated atomizer, and cotton soaked in e-liquid (6). The majority of Cig-a-likes are built with low-voltage batteries and low-volume, non-refillable reservoirs made of sponge-like polyfill (Fig. 1) (7).

The second generation had the enhancement of a high-capacity rechargeable battery and a separated tank (6). As the years passed and ECIG technology improved, thirdand fourth-generation 'intelligent vaping systems' included new features, such as voltage regulation from 3.4 to $4.8 \mathrm{~V}$, battery improvement (third generation), and better internal device resistances (fourth generation) (Fig. 1) (6).

Fourth generation ECIGs were introduced in the last 5 years. Also known as 'Pod-Mods', they are new and highly popular. Their main innovation is fusing atomizer and tank in a simplified piece, known as a 'Pod,' that contains and vaporizes the e-liquid. The Pod is fastened to an USB or to a tear-shaped rechargeable battery. Another difference in 'Pod-Mods' is the use of a new e-liquid formula with protonated nicotine. Inhaling these new formulas do not cause the side-effects caused by high-nicotine concentrations. This innovation increases acceptance rates and increases the risk of addiction among young users (Fig. 1) (8).

Some ECIGs are designed to be totally disposable. The majority of other ECIGs are reusable. The reusable contain a rechargeable lithium battery and a replaceable vaporization chamber, wicking system, and nicotine/flavoring cartridge (9).
A survey conducted by the National Youth Tobacco Survey (NYTS) to estimate the prevalence of ECIGs in the United States from 2011 to 2012 demonstrated that 1.78 million students had used ECIGs in that time period. In 2012, approximately 160,000 students using ECIGs had never used conventional cigarettes (10). In a recent study, 4.04 million high-school students and 840,000 middle-school students were at that time using some tobacco product; ECIGs were used the most (11).

\section{Chemical compounds found in ECIGs}

Along with characteristic tobacco odor and flavor options, one of the most attractive features of ECIGs for younger individuals is the perception that consumption has a 'low risk' to health (12). While the use of ECIGs does reduces consumption levels of toxic compounds compared to traditional cigarettes, it remains a source of exposure to harmful substances.

Some investigations have examined the chemical composition of commercial e-liquids from $>50$ brands. An average of 87 (from 60 to 113) chemical compounds were identified in ECIGs cartridges, e-liquids and aerosols (13-15). Compounds identified in ECIG liquids and aerosols include nicotine, solvent vehicles such as propylene glycol (PG) and glycerol; tobacco-specific nitrosamines (TSNAs), aldehydes, metals, volatile organic compounds (VOCs), phenolic compounds, polycyclic aromatic hydrocarbons (PAH), flavorings, and minor tobacco alkaloids (Fig. 2) $(13,16,17)$. 


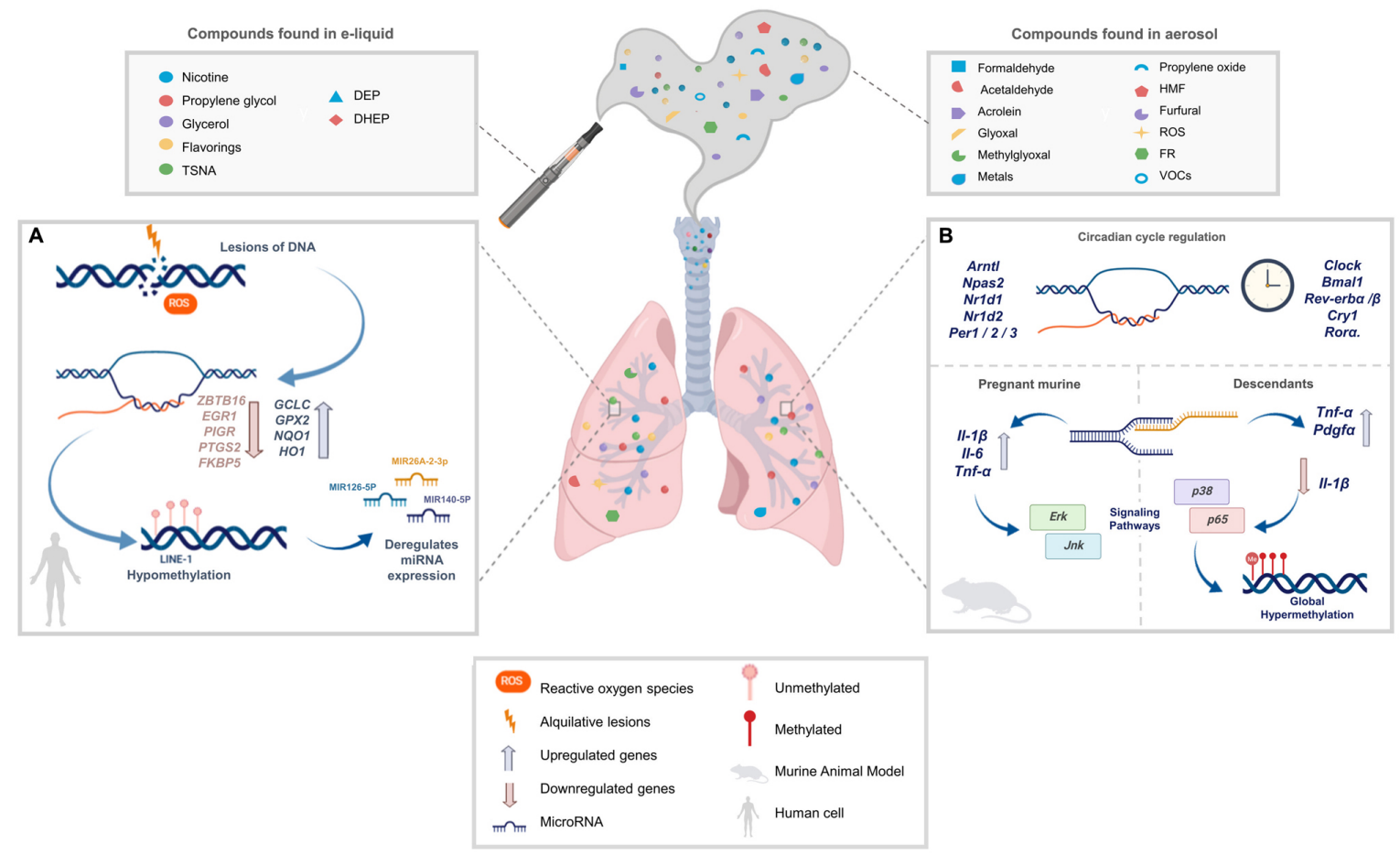

Figure 2. Pulmonary genetic and epigenetic impact of chemical components derived from ECIGs. Summary of the main chemical components found in e-liquids and aerosols and schematic representation of their genetic and epigenetic effects, which are evidenced in studies in (A) humans and (B) mice. (A) Exposition of ECIGs aerosol in humans may cause oxidative and alkylating lesions directly over the DNA. It also causes transcriptome alterations, such as reduced expression of genes related to the immune system and an increased expression of genes involved in the oxidative stress response. As regards the effects ECIGs on the epigenome, the hypomethylation of class I transposable elements (LINE-1) and the dysregulation of miRNA expression should be highlighted. (B) Following ECIGs aerosol exposition in a murine model, the alteration of genes involved in control and correct functioning of circadian rhythm is evidenced. Another murine model demonstrated that ECIG aerosol intake was detrimental to fetal and maternal respiratory health $(56,57)$. This effect was due to an induction of inflammatory response at pulmonary tissue in mother and litter. Specifically, an increased expression of IL-1 $\beta$, IL- 6 and TNF- $\alpha$ and altered ERK1/2 and JNK pathways are being identified in mouse mothers. Also, an increase of TNF- $\alpha$ and PDGF $\alpha$ expression, a decrease of IL-1 $\beta$ expression, and a dysregulation of p38 and p65 pathways are identified in their breed. Vapor produced by ECIGs leads to changes on the epigenetic profile of exposed breed in utero, where a global hypomethylation state is being shown. The figure was created with BioRender.com. ECIGs, electronic cigarettes.

Currently, there are $>7,000$ flavorings for ECIGs (18), which are manufactured using chemical compounds such as alcohols, acids, esters, lactones, aldehydes, ketones, heterocycles and mercaptans (Table I). These flavorings, as well as propylene glycol (PG) and glycerol, are classified as 'generally recognized as safe' (GRAS) by the FDA $(12,19)$, which suggests that they are safe to consume if they are used as food additives. However, other administrations, such as inhalation, may be harmful. Although data on long-term inhalation exposure to PG and glycerol is currently limited $(20,21)$, exposure to $P G$ is known to cause irritation to the eyes and respiratory tract $(13,22)$, in addition to increasing the probability of developing asthma (23-25).

Even more compounds (approximately 18) are observed in the inhaled aerosols, given that additional chemicals are generated at high temperatures during vaporization (14). Some are potentially harmful chemicals and ultrafine particles, including carbonyl compounds, VOCs, TSNAs, metals and silicates (Fig. 2) (26). These substances are potentially toxic and carcinogenic, and they increase the risk of respiratory and heart diseases (13). The heating of flavorings generates other substances in quantities exceeding the maximum limit allowed, including aldehydes, toxic furans, benzene, methanol and ethanol. These can produce multiple adverse health effects (27-29). When PG and glycerol are heated to high temperatures and aerosolized, thermal dehydration reactions are facilitated, and several toxic carbonyl compounds are generated (30). Recent studies in e-liquids have found toxic carbonyls such as formaldehyde, acetaldehyde, acrolein, glyoxal, and methylglyoxal, in addition to propylene oxide, all known to be potentially carcinogenic and causing irritation of the upper respiratory tract (Table I) $(22,31-36)$. What is of concern is that the numbers of substances and their concentrations are highly variable, due to the differences in the manufacturing of ECIGs. Temperature can influence a higher production of carbonyl compounds $(31,37)$. In some studies, as voltage rises to heat devices, formaldehyde, acetaldehyde and acetone levels increase as much as 200 percent, representing a major risk to health $(38,39)$.

TSNAs are found in some ECIGs and have a high carcinogenic potential. They form in the curing process during the nitrosation of amines $(40,41)$. Minor alkaloids have also been found; however, their effects on health are currently unknown (30). Other relevant compounds are diethyl phthalate (DEP) and di-2-ethylhexyl phthalate (DHEP). They probably develop from the e-liquid package in the production process and have serious adverse effects on health $(42,43)$.

Various studies have detected different metals in e-liquids and their aerosols (Table I) $(13,44)$. The levels and concentrations of these metals, except for cadmium, are higher compared to those in traditional cigarettes. These metals can originate in the chamber that aerosolizes the e-liquid, or from 
Table I. Main chemical compounds found in electronic cigarettes.

\begin{tabular}{|c|c|c|c|c|c|}
\hline $\begin{array}{l}\text { Chemical } \\
\text { group }\end{array}$ & $\begin{array}{l}\text { Chemical } \\
\text { compound }\end{array}$ & Source & $\begin{array}{l}\text { Main health effects } \\
\text { from exposure }\end{array}$ & $\begin{array}{l}\text { Respiratory or } \\
\text { lung irritant }\end{array}$ & (Refs.) \\
\hline Acids & Butyric acid & $\begin{array}{l}\text { E-liquid } \\
\text { flavors }\end{array}$ & Moderate skin and eye irritation & No evidence & (13) \\
\hline \multirow[t]{3}{*}{ Alcohols } & Menthol & & Skin irritation and severe eye irritation & No evidence & (13) \\
\hline & Benzaldehyde & & $\begin{array}{l}\text { Aerosolized form generates irritation } \\
\text { in the membranes of the airways }\end{array}$ & Yes & $(28)$ \\
\hline & Cinnamaldehyde & & $\begin{array}{l}\text { Damage to the homeostasis of the } \\
\text { respiratory system, increase in DNA } \\
\text { breaks, decrease in cell growth } \\
\text { and increase in cell death }\end{array}$ & Yes & $(27)$ \\
\hline \multirow[t]{4}{*}{ Heterocycles } & Furfural & $\begin{array}{l}\text { E-liquid } \\
\text { aerosol }\end{array}$ & Exhibits tumorigenicity in mice & Yes & $(13,29)$ \\
\hline & 5-Hydroxymethylfurfural & & Exhibits tumorigenicity in mice & Yes & $(22,29)$ \\
\hline & Maltol & & Cytotoxic & Yes & $(13)$ \\
\hline & 2-Acetylpyrrole & & Skin irritation & Yes & \\
\hline \multirow[t]{3}{*}{ Solvents } & Glycerol & E-liquid & $\begin{array}{l}\text { Associated to lipoid pneumonia } \\
\text { Minimal squamous metaplasia } \\
\text { of the epiglottis }\end{array}$ & Yes & $(25)$ \\
\hline & Propylene glycol & & $\begin{array}{l}\text { Increases the risk of developing } \\
\text { asthma and irritates eyes }\end{array}$ & Yes & $(13,25)$ \\
\hline & Ethylene glycol & & Harmful effects in animal models & Yes & $(21)$ \\
\hline \multirow[t]{5}{*}{ Carbonyl } & Formaldehyde & $\begin{array}{l}\text { E-liquid } \\
\text { aerosol }\end{array}$ & $\begin{array}{l}\text { Classified as a human } \\
\text { carcinogen (Group 1) }\end{array}$ & No evidence & $(22)$ \\
\hline & Acetaldehyde & & $\begin{array}{l}\text { Classified as possibly carcinogenic } \\
\text { to humans (Group 2B) }\end{array}$ & No evidence & $(22)$ \\
\hline & Acrolein & & $\begin{array}{l}\text { Causes irritation of the nasal cavity } \\
\text { and damages the lining of the lungs } \\
\text { through oxidative stress and its } \\
\text { involved in COPD development }\end{array}$ & Yes & $(13,41)$ \\
\hline & Propylene oxide & & $\begin{array}{l}\text { Classified as potentially } \\
\text { carcinogenic by the IARC }\end{array}$ & Yes & $(31)$ \\
\hline & Glyoxal & & Shows mutagenicity & No evidence & (36) \\
\hline \multirow[t]{2}{*}{$\begin{array}{l}\text { Nitrosamines } \\
\text { (TSNAs) }\end{array}$} & $\begin{array}{l}\text { N'-nitrosonornicotine } \\
(\mathrm{NNN})\end{array}$ & $\begin{array}{l}\text { E-liquid } \\
\text { with } \\
\text { nicotine }\end{array}$ & $\begin{array}{l}\text { Low levels have been found. } \\
\text { Are potent carcinogenic chemicals. } \\
\text { Can cause throat or mouth cancer }\end{array}$ & No evidence & $(41,42)$ \\
\hline & N'-nitrosoanabasine (NAB) & & $\begin{array}{l}\text { Classified as a human carcinogen } \\
\text { (Group 3) }\end{array}$ & No evidence & \\
\hline \multirow[t]{2}{*}{ VOCs } & Benzene & $\begin{array}{l}\text { E-liquid } \\
\text { aerosol }\end{array}$ & $\begin{array}{l}\text { Classified as highly carcinogenic } \\
\text { by the IARC, related to depression } \\
\text { of the CNS when inhaled }\end{array}$ & Yes & $(13,26)$ \\
\hline & Methanol & & $\begin{array}{l}\text { Increases the risk of developing } \\
\text { myeloid leukemia and affection of } \\
\text { sexual organs, also its metabolites } \\
\text { are toxic and may cause eye damage }\end{array}$ & Yes & \\
\hline \multirow[t]{2}{*}{ Phthalates } & $\begin{array}{l}\text { Diethyl phthalate } \\
\text { (DEP) } \\
\text { Di-2-ethylhexyl phthalate } \\
\text { (DHEP) }\end{array}$ & $\begin{array}{l}\text { E-liquid } \\
\text { package }\end{array}$ & $\begin{array}{l}\text { Favors inflammation and } \\
\text { oxidative stress, and are risk factors } \\
\text { for the development of neurological, } \\
\text { gastrointestinal and asthma disorders. } \\
\text { DHEP is classified as probably } \\
\text { carcinogenic }\end{array}$ & Yes & (44) \\
\hline & & & & Yes & \\
\hline Metals & Nickel & $\begin{array}{l}\text { Probably } \\
\text { from ECIGs } \\
\text { chamber }\end{array}$ & $\begin{array}{l}\text { Impaired lung function, classified } \\
\text { as a human carcinogen (Group 1). }\end{array}$ & Yes & $(45-48)$ \\
\hline
\end{tabular}


Table I. Continued.

\begin{tabular}{|c|c|c|c|c|c|}
\hline $\begin{array}{l}\text { Chemical } \\
\text { group }\end{array}$ & $\begin{array}{l}\text { Chemical } \\
\text { compound }\end{array}$ & Source & $\begin{array}{l}\text { Main health effects } \\
\text { from exposure }\end{array}$ & $\begin{array}{l}\text { Respiratory or } \\
\text { lung irritant }\end{array}$ & (Refs.) \\
\hline & Copper & & $\begin{array}{l}\text { Mitochondrial oxidative stress } \\
\text { and DNA fragmentation }\end{array}$ & No evidence & \\
\hline & Cadmium & & May cause toxicity to multiple organs & & \\
\hline & Manganese & & & & \\
\hline & Aluminum & & & & \\
\hline & Iron & & Impaired lung function and fibrosis & Yes & \\
\hline
\end{tabular}

VOCs, volatile organic compounds.

other ECIGs components that infiltrate the aerosol $(13,45)$. One study reported that these metals might be inhaled, affecting normal chromium and nickel body levels, resulting in high toxicity to multiple organs (46). Copper is specifically associated with mitochondrial oxidative stress and DNA fragmentation $(13,46,47)$.

Finally, reactive oxygen species (ROS) and free radicals (FRs) are produced by normal aerobic metabolism and can also be derived from external sources, such as tobacco smoke. The increase in ROS and FR creates homeostatic imbalance and oxidative stress, which exerts negative effects, such as breakdowns in cellular function and cellular damage (48). This may trigger cardiovascular and respiratory diseases (chronic obstructive pulmonary disease, asthma) and even cancer development, due to DNA damage.

In summary, the majority of ECIGs, regardless of their nicotine content, contain and emit potentially toxic substances that may, with long-term exposure, alter the homeostasis of certain organs and can cause damage. These changes in microenvironment exposure may alter the epigenome, transcriptome, and even the genome itself. Those effects of vaping will be the main focus of discussion below.

\section{Noxious effects of ECIGs on DNA}

Aerosol generated by ECIGs is composed of various toxic agents. Some are reported to exert an effect at the cellular level similar to that of tobacco smoke, principally increased levels of oxidative stress and inflammation (49), and to lead to changes in gene expression $(50,51)$.

For this reason, it is essential to determine whether ECIG aerosol exposure can cause DNA damage to pulmonary and oral epithelial cells. Ganapathy et al (52) determined the genotoxicity and mechanisms induced by ECIG aerosol extract in human epithelial normal bronchial cells (Nuli1) and human oral squamous cell carcinoma (UM-SCC-1). After $1 \mathrm{~h}$ of aerosol exposure in both cell types, oxidative and alkylation DNA lesions were observed. It was also shown that DNA damage was dose-dependent, as more damage was evidenced as exposure to ECIG aerosols increased (Table II). These harmful effects may be associated with formaldehyde and the ROS levels in aerosols (Fig. 2A) (52).

The significant mutagenic capacity of toxic compounds in ECIGs has not yet been described, at least to the best of our knowledge. However, conventional smoking has been proven to cause multiple epigenetic alterations. Given that ECIGs contain numerous noxious chemical compounds, they can alter epigenetic mechanisms that regulate gene expression as well.

Toxic chemicals in ECIGs can generate changes in the cellular microenvironment, leading to deregulation in gene expression through epigenetic alterations, such as DNA aberrant methylation or hypomethylation, histone modifications, chromatin remodeling and microRNA (miRNA/miR) expression. Alterations in these mechanisms can support the development of different pathologies, particularly in the lungs (53).

\section{Effect ECIGs on genes involved in the immune response}

The study by Martin et al (54) in 2016 on conventional smokers, non-smokers and ECIG users, compared the expression of 597 genes in nasal mucous epithelial cells related to the immune response. The expression of 53 genes in smokers and 305 in ECIGs users decreased (Table II).

It is important to note that the decrease in the expression of genes associated with exposure to conventional cigarettes was also observed in cells exposed to ECIGs. The levels of the early growth response protein 1 (EGRl), dipeptidyl peptidase-4 (DPP4), chemokine (C-X-C motif) ligand 2 (CXCL2), $\mathrm{CX} 3 \mathrm{C}$ chemokine receptor $1(C X 3 C R 1)$ and cluster of differentiation $28(C D 28)$ genes were shown to be downregulated in conventional cigarette smokers, while the levels of the zinc finger and BTB domain-containing protein 16 (ZBTB16), $E G R 1$, polymeric immunoglobulin receptor (PIGR), prostaglandin-endoperoxide synthase 2 (PTGS2) and FKBP prolyl isomerase 5 (FKBP5) genes were downregulated in ECIG users. The majority of the downregulated genes in cigarette smokers and ECIG users code for transcription factors (TFs) that regulate downstream genes associated with the immune system (54). One of these is the colony-stimulating factor $1(C S F-1)$, a gene that codes for a cytokine involved in the activation of innate immunity in infection response (55). The $C S F-1$ is a target of EFR1 TF, the expression of which is significantly decreased in smokers and ECIG users (Fig. 2A). This suggests that the use of ECIGs may induce immunosuppression states associated with the suppression of the expression of genes involved in the immune response of nasal mucous cells. This may increase susceptibility to various infections (Table II) (54). 


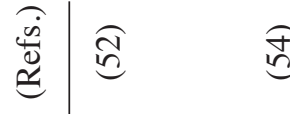

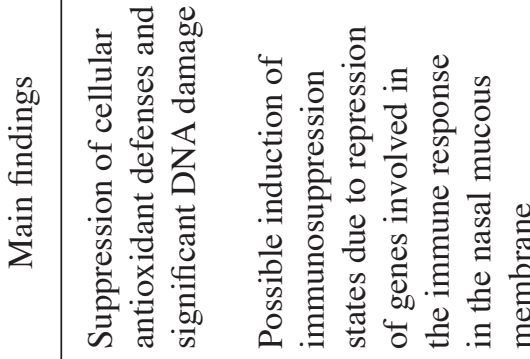

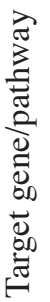

$\stackrel{\pi}{\stackrel{2}{2}}$

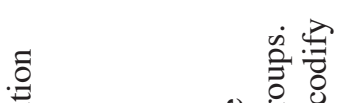

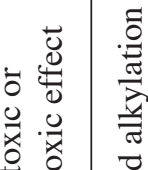

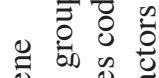

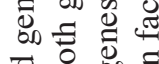

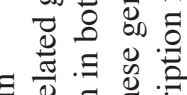

$\exists \frac{\pi}{0} . \Xi$.

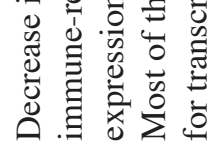

突

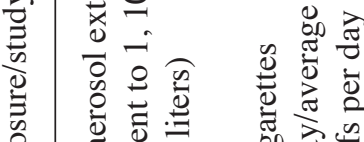

这

峁

文

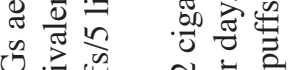

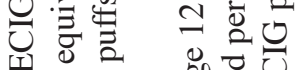

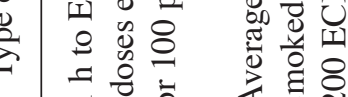

二 व्रें है

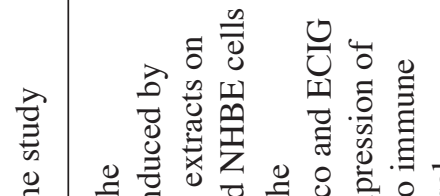

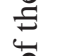

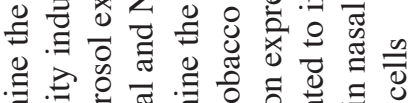

灵

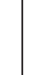

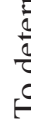

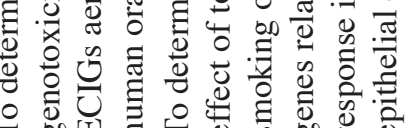

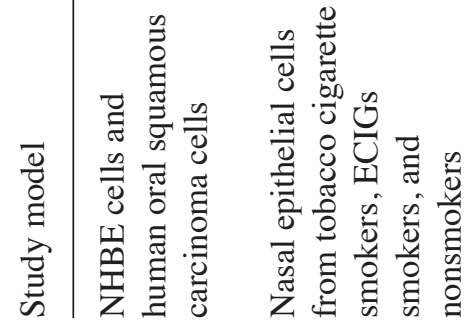

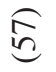

$\stackrel{6}{\circ}$

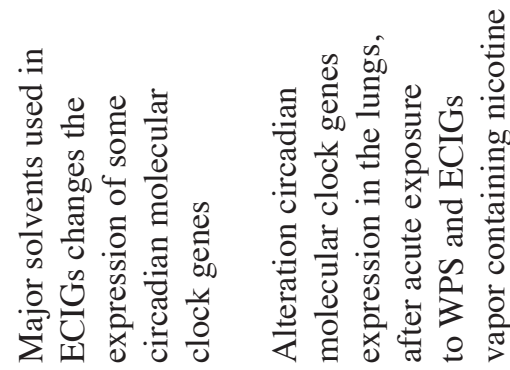

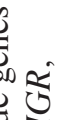

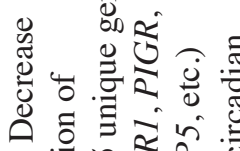

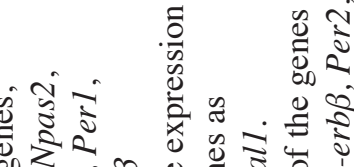

J

จ.

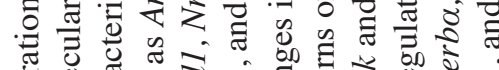

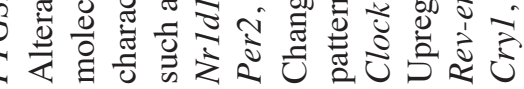

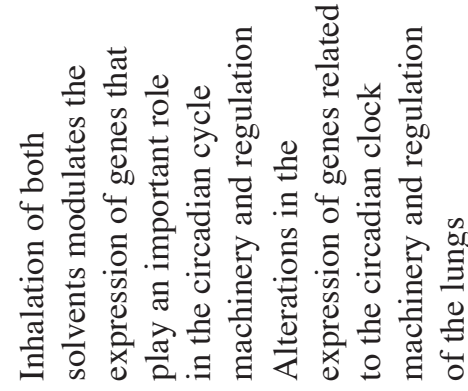

छे

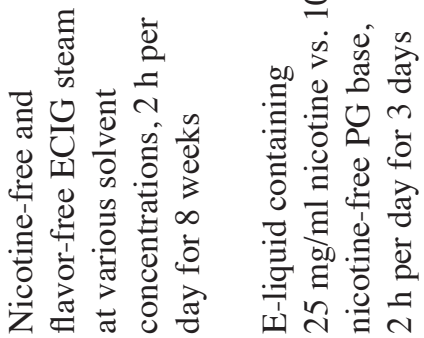

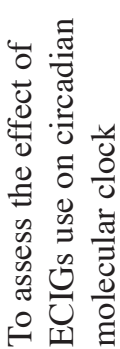

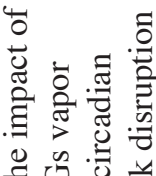

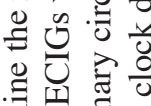

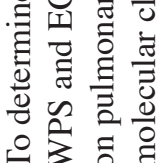

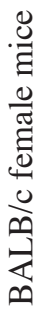

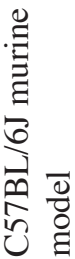




\section{Effect of ECIGs on genes involved in the circadian clock}

The circadian molecular clock is important for homeostasis and biologic functions, such as glucose metabolism and immune/inflammatory responses. Circadian clock disruption in the lungs may alter respiratory function and affect inflammatory responses. ROS production may cause DNA damage and mucus hypersecretion, contributing to the development and advance of chronic obstructive pulmonary disease (COPD) (56). Alterations in organs other than the lungs have been associated with the development of cancer, obesity and cardiovascular risk, among other illnesses (57).

E-liquids contain a high amount of PG and glycerol. To assess the effects of these substances on health, a previous study exposed a murine model (female BALB/c) to steam from nicotine-free and flavor-free ECIGs at various solvent concentrations (PG 70\% and glycerol 30\%, glycerol 100\% and PG 100\%) (57). The lung transcriptomic results revealed that the inhalation of both components modulated the expression of 37 genes, most conspicuously aryl hydrocarbon receptor nuclear translocator like (Arntl), neuronal PAS domain protein 2 (Npas2), nuclear receptor subfamily 1 group D member 1 (Nrld1), nuclear receptor subfamily 1 group D member 2 (Nrld2), period circadian regulator (Per), Per2 and Per3. These genes belong to the circadian clock machinery and play an important role in circadian cycle regulation. Surprisingly, these affected genetic expression not only in pulmonary tissue, but also in the liver, brain, skeletal muscle and kidneys (Table II). Likewise, the expression of the heat shock $70 \mathrm{kDa}$ protein 1 (Hspala, also known as Hsp72) and heat shock protein family A (Hsp70) member 1B (Hspalb) genes, Hsp70 member was altered following exposure to PG and glycerol, suggesting that although Hspala and Hspalb are not part of the circadian clock control, they may be affected because their expression depends on this physiologic process (Fig. 2B) (57).

A similar study by Khan et al (56) demonstrated that chronic exposure to smoke and aerosols from ECIGs and water-pipes in a $\mathrm{C} 57 \mathrm{BL} / 6 \mathrm{~J}$ murine model produced specific pulmonary alterations to the abundance and expression of genes related to the circadian clock control and to the output of genes controlled by the circadian clock. Water-pipe smoke exposure produced alterations in the circadian clock expression patterns of the pulmonary-specific genes, Clock and Bmall, and in the upregulation of the output genes, Rev-erb $\alpha, \operatorname{Rev}-\operatorname{erb} \beta, P e r 2$, Cryl and Ror $\alpha$ (Fig. 2B). Exposure to ECIG aerosols also alters circadian clock genetic expression in lung tissue, particularly when e-liquids contain nicotine (Table II) (56).

\section{Effects of ECIGs on the epigenome}

Smoking tobacco cigarettes has been one of the risk factors most related to epigenome alterations. Recently the impact of ECIGs on the epigenome has also been questioned. Caliri et al (58) proved the association between vaping and a loss of DNA methylation levels. They analyzed peripheral blood samples of ECIGs users, conventional smokers and non-smokers for methylation levels $(5-\mathrm{mC})$ on the transposable elements, long interspersed nucleotide element 1 (LINE-1). The loss of methylation in LINE-1 coding regions results in latent retrotransposon activation. This can lead to a genomic instability status, a hallmark of cancer. Their study demonstrated a significant decrease in methylation $(5-\mathrm{mC})$ in LINE-1 elements (Fig. 2A), 18\% in vapers and 13\% in cigarette smokers, compared to a non-smoker control group, with no significant differences between vapers and smokers. The hydroxymethylation $(5-\mathrm{hmC})$ was also quantified on the DNA, decreased in vapers (66\%) and cigarette smokers (88\%) (58). Epigenetic alterations found in that study are linked to DNA hypomethylation, and they suggest a possible association between ECIGs use and cancer risk (Table II).

Exposure to liquids and aerosols of ECIGs, with or without nicotine, induces the gene expression of glutamate-cysteine ligase catalytic subunit $(G C L C)$, glutathione peroxidase 2 $(G P X 2), \mathrm{NAD}(\mathrm{P}) \mathrm{H}$ dehydrogenase [quinone] 1 (NQO1) and heme oxygenase $1(\mathrm{HOl})$ in response to oxidative stress in normal human bronchial epithelial cells (NHBE). The maximum response to oxidative stress is produced when ECIG aerosols contain nicotine (59).

On the other hand, exposure to ECIGs deregulates the expression of $>125$ miRNAs. This was first evidenced by Solleti et al (59), using RNA-seq. These results confirmed the increased expression of the miRNAs, miR-26A-2-3p, miR-126-5P, miR-140-5P, miR-29A-2-5P, miR-374A-3P and miR-147B. The results were focused on miR-126-5P, expressed in highly vascularized tissues like that found in lungs and the heart, inducing the decrease in its gene targets, MAS-related G-protein coupled receptor member X3 (MRGPRX3) and MYC, involved in apoptosis, transformation and cellular differentiation processes (Table II). This exposure also increases NQO1 protein and $\mathrm{HO} 1$ enzyme expression, both with antioxidative function in response to oxidative stress (Fig. 2A) (59).

It is currently known that conventional cigarette consumption during pregnancy is detrimental to fetal respiratory health, increasing post-natal susceptibility to respiratory infections and pulmonary dysfunction $(1,2,32,34)$. For this reason, some have the perception that the use of ECIGs is a safer smoking alternative and acceptable for use by pregnant women.

In pregnant murine models (BALB/c mice) exposed to ECIGs, with and without nicotine, epigenetic alterations were observed, among mothers and their descendants, in genes involved in the inflammatory response of the lungs $(56,57)$. The expression of the genes, interleukin (Il)-1 $\beta$, Il-6 and tumor necrosis factor (Tnf)- $\alpha$ increased in the lungs of mothers and the hatchlings exhibited an increased Tnf- $\alpha$ expression, but decreased $I l-1 \beta$ levels. In addition, signaling routes involved in the inflammatory response were differentially altered in mothers and hatchlings, with changes on the Erk1/2 and Jnk expression in mothers and p38 and p65 changes in hatchlings (Table II) (54,56-62).

The intrauterine exposure of mice to ECIGs with or without nicotine has revealed increased mRNA levels of platelet-derived growth factor $\alpha$-receptor $(P d g f \alpha)$ in the postnatal stage. An increment in $P d g f \alpha$ expression has been shown to be involved in the pathologic process of pulmonary fibrosis (61). In uterus, ECIG aerosol exposure produces epigenetic alterations. An increase in global methylation was previously evidenced in the lungs of BALB/c mice hatchlings exposed to ECIGs during pregnancy, regardless of the nicotine concentration (Fig. 2B) (61).

Apart from altering the genetic expression of molecules related to the inflammatory response and the methylation of 
fetal DNA, it has been evidenced in different animal models that ECIG exposure generates embryonic development alterations. Exposure to ECIG aerosols provokes orofacial alteration during Xenopus laevis embryonic development. These may include middle facial cleft, middle face hypoplasia, and alterations of muscle development and vasculature distribution (54,56-62).

These alterations also occur in mammals. The aberrant expression of the vasculogenesis gene, vascular endothelial growth factor (VEGF) and the markers involved in the formation of Fgf2, Sox9, and Col2a1 cartilage were observed in the murine neural crest cell line, O91, following exposure to different brands of electronic cigarettes (Table II) (54,56-62).

These alterations are caused by ECIGs components, such as $\mathrm{PG}$, vegetal glycerin and various concentrations of nicotine in the e-liquids (62). This evidence suggests that vaping during pregnancy may exert adverse effects, such as those caused by traditional smoking. Further investigations however, are necessary to fully elucidate these effects.

\section{Effects of nicotine administration systems on pulmonary function}

There is limited information regarding the effects of vaping on pulmonary function. Several studies have evaluated the acute effects, demonstrating variable results (63). In the study conducted by Flouris et al (64), the acute impact of active and passive ECIGs smoking on serum nicotine and lung function was assessed and compared to active and passive tobacco cigarette smoking. The results revealed that ECIGs and tobacco cigarettes generated similar $(\mathrm{P}<0.001)$ effects on serum nicotine levels with active and passive smoking. There was no significant difference in pulmonary function parameters between active and passive ECIGs smoking $(64,65)$.

Ferrari et al (66) performed a study comparing the effects of using nicotine-free ECIGs and traditional cigarettes for 5 min in healthy adult smokers $(n=10)$ and non-smokers $(n=10)$, evaluating pulmonary function. As was expected, traditional cigarettes induced a significant decrease from baseline in forced expiratory flow at $75 \%$ of vital capacity (FEF75) in non-smokers. There were significant decreases in forced expiratory flow at $25 \%$ of vital capacity (FEF25), forced expiratory volume in 1 sec (FEV1), and peak expiratory flow (PEF) in smokers. The only statistically significant effects induced by the nicotine-free ECIGs in smokers were reductions in FEV1 and FEF25 (66). Other studies found that acute exposure to ECIGs induced vasoreactivity and decreased PEF, though they identified non-significant changes in FEV1, forced vital capacity (FVC), and the ratio between FEV1 and FVC (FEV1/FVC) (67).

A randomized trial in Brussels with 30 patients (68) demonstrated that acute nicotine and nicotine-free vaping decreased transcutaneous oxygen tension $\left(\mathrm{TcpO}_{2}\right)$ and slightly decreased peripheral oxygen saturation $\left(\mathrm{SpO}_{2}\right)$ despite its lack of sensitivity to small changes in arterial $\mathrm{O}_{2}$ partial pressure. This further indicates potential disturbances in lung gas exchanges caused by vaping.

In another randomized, double-blind study, occasional smokers (maximum 10 tobacco cigarettes per month) were exposed to ECIGs aerosol for $30 \mathrm{~min}$ following a washout period of 1 week minimum. Dynamic spirometry and impulse oscillometry were then evaluated. The results revealed a significant decrease in vital capacity and resonance frequency, but increased levels of fractional exhaled nitric oxide and increased resistance to airflow, indicating an obstructive pattern after the exposure (69).

As presented above, a number of studies have explored short-term effects of vaping. Information on the long-term effects is limited; however, generating increasing concern. A recent observational 3.5 year-study compared health outcomes in 9 daily ECIGs users who had never smoked tobacco and a control group of 12 individuals who had never smoked. The results revealed no statistically significant changes from baseline in the EC users (or between EC users and controls) in any of the investigated health outcomes [blood pressure, heart rate, body weight, lung function, respiratory symptoms, exhaled nitric oxide (eNO), exhaled carbon monoxide (eCO) and high-resolution computed tomography (HRCT)] (70).

Due to the newness of vaping and the multitude of devices, flavorings and nicotine concentrations on the market, there is a shortage of data regarding its long-term effects on the respiratory system. The consequences of long-term vaping remain unclear (71). Further studies are required to pinpoint involved pathogenesis mechanisms, and to identify the potential long-term consequences of ECIG usage.

To date, there are no specific policies on the manufacturing standards of e-cigs. As regards ECIs regulation, the WHO Framework Convention for Tobacco Control (FCTC/Law 1109 of 2006) at the seventh meeting of WHO Framework Convention on Tobacco Control, invited FCTC parties to consider prohibiting or regulating ECIGs. On the other hand, the United States Congress raised the minimum age to buy tobacco and electronic cigarettes in the country from 18 to 21 years of age on November, 2019; the measure approved was far from what the US administration was considering a total prohibition on flavored electronic cigarettes (72-75).

\section{Conclusion}

The majority of ECIGs, whether they contain nicotine or not, emit potentially toxic substances when used. What is of concern is that the number of these toxic substances and their concentration are highly variable, as are the manufacturing specifications for, as well as ECIGs manufacturing characteristics. This variability may result in increased exposure to these compounds with clinically demonstrated adverse health effects. While the use of ECIGs reduces the consumption of toxic compounds compared to traditional cigarettes, it remains a source of exposure to substances with high carcinogenic potential that alter epigenomic and transcriptomic processes, promote cell injury, hijack normal inflammatory response and, at high doses, affect normal fetal development. Further investigations are required in order to better understand the underlying mechanisms. Preventive measures and guidelines for the use of these devices can then be established.

\section{Acknowledgements}

Not applicable. 


\section{Funding}

The present study was supported by the Hospital Universitario San Ignacio-Research Office

\section{Availability of data and materials}

Not applicable.

\section{Authors' contributions}

NN, LGB, DMG, CB, FG, DL, MJP, CC, IM, PS, AR, SH, $\mathrm{CT}, \mathrm{SRA}, \mathrm{RC}$ and $\mathrm{MG}$ contributed to manuscript writing and data/literature searching for this review. AC and AR contributed to the concept and design of the study, and to manuscript writing. All authors read and approved the final manuscript.

\section{Ethics approval and consent to participate}

Not applicable.

\section{Patient consent for publication}

Not applicable.

\section{Competing interests}

The authors declare that they have no competing interests.

\section{References}

1. Herr C, Tsitouras K, Niederstraßer J, Backes C, Beisswenger C, Dong L, Guillot L, Keller A and Bals R: Cigarette smoke and electronic cigarettes differentially activate bronchial epithelial cells. Respir Res 21: 67, 2020.

2. Gilbert AH: Smokeless non-tobacco cigarette. US Patent US3200819A. Filed April 17, 1963; issued August 17, 1965.

3. Franck C, Budlovsky T, Windle SB, Filion KB and Eisenberg MJ: Electronic cigarettes in North America: History, use, and implications for smoking cessation. Circulation 129: 1945-1952, 2014

4. Hammond D, Reid JL, Rynard VL, Fong GT, Cummings KM, McNeill A, Hitchman S, Thrasher JF, Goniewicz ML, Bansal-Travers M, et al: Prevalence of vaping and smoking among adolescents in Canada, England, and the United States: Repeat national cross sectional surveys. BMJ 365: 12219, 2019. Erratum in: BMJ 370: m2579, 2020.

5. Grana A, Benowitz M and Stanton GA: Background Paper on E-cigarettes (Electronic Nicotine Delivery Systems). UCSF WHO Tobacco Control Papers, 2013.

6. Protano C, Avino P, Manigrasso M, Vivaldi V, Perna F, Valeriani $\mathrm{F}$ and Vitali M: Environmental electronic vape exposure from four different generations of electronic cigarettes: Airborne particulate matter levels. Int J Environ Res Public Health 15: 2172, 2018

7. Farsalinos KE, Gillman G, Thornburg JW, Hecht SS and Polosa R: Analytical assessment of e-cigarettes: From contents to chemical and particle exposure profiles. Elsevier, 2016.

8. Barrington-Trimis JL and Leventhal AM: Adolescents' Use of 'Pod Mod' E-Cigarettes - Urgent Concerns. N Engl J Med 379: 1099-1102, 2018.

9. Marcham CL and Springston JP: Electronic cigarettes in the indoor environment. Rev Environ Health 34: 105-124, 2019.

10. Corey C, Wang B, Johnson SE, et al; Centers for Disease Control and Prevention (CDC): Notes from the field: Electronic cigarette use among middle and high school students - United States, 2011-2012. MMWR Morb Mortal Wkly Rep 62: 729-730, 2013.

11. Gentzke AS, Creamer M, Cullen KA, Ambrose BK, Willis G, Jamal A and King BA: Vital Signs: Tobacco product use among middle and high school students - United States, 2011-2018. MMWR Morb Mortal Wkly Rep 68: 157-164, 2019.
12. Barrington-Trimis JL, Berhane $\mathrm{K}$, Unger JB, Cruz TB, Huh J, Leventhal AM, Urman R, Wang K, Howland S, Gilreath TD, et al: Psychosocial factors associated with adolescent electronic cigarette and cigarette use. Pediatrics 136: 308-317, 2015.

13. Stratton K, Kwan LY and Eaton DL: Public Health Consequences of E-Cigarettes. The National Academies Press, 2018.

14. Herrington JS and Myers C: Electronic cigarette solutions and resultant aerosol profiles. J Chromatogr A 1418: 192-199, 2015.

15. Kucharska M, Wesołowski W, Czerczak S and Soćko R: Testing of the composition of e-cigarette liquids - Manufacturer-declared vs. true contents in a selected series of products. Med Pr 67: 239-253, 2016 (In Polish).

16. Hahn J, Monakhova YB, Hengen J, Kohl-Himmelseher M, Schüssler J, Hahn H, Kuballa T and Lachenmeier DW: Electronic cigarettes: Overview of chemical composition and exposure estimation. Tob Induc Dis 12: 23, 2014.

17. Sassano MF, Davis ES, Keating JE, Zorn BT, Kochar TK, Wolfgang MC, Glish GL and Tarran R: Evaluation of e-liquid toxicity using an open-source high-throughput screening assay. PLoS Biol 16: e2003904, 2018.

18. Zhu SH, Zhuang YL, Wong S, Cummins SE and Tedeschi GJ: E-cigarette use and associated changes in population smoking cessation: Evidence from US current population surveys. BMJ 358: j3262, 2017.

19. U.S. Food and Drug Administration (FDA): Select committee on GRAS substances opinion: Propylene glycol and propylene glycol monostearate. FDA, Washington, DC, 1973.

20. Jimenez Ruiz CA, Solano Reina S, de Granda Orive JI, Signes-Costa Minaya J, de Higes Martinez E, Riesco Miranda JA, Altet Gómez N, Lorza Blasco JJ, Barrueco Ferrero M and de Lucas Ramos P: The electronic cigarette. Official statement of the Spanish Society of Pneumology and Thoracic Surgery (SEPAR) on the efficacy, safety and regulation of electronic cigarettes. Arch Bronconeumol 50: 362-367, 2014 (In English).

21. Gomes R, Liteplo R and Meek ME: Ethylene glycol: human health aspects. World Health Organization, Geneva, 2002.

22. Grana R, Benowitz N and Glantz SA: E-cigarettes: A scientific review. Circulation 129: 1972-1986, 2014.

23. Oh AY and Kacker A: Do electronic cigarettes impart a lower potential disease burden than conventional tobacco cigarettes? Review on E-cigarette vapor versus tobacco smoke. Laryngoscope 124: 2702-2706, 2014.

24. German Cancer Research Center (ed): Electronic Cigarettes-An Overview. Vol 19. German Cancer Research Center, Heidelberg, 2013.

25. Papaefstathiou E, Stylianou M and Agapiou A: Main and side stream effects of electronic cigarettes. J Environ Manage 238: 10-17, 2019

26. Copaja MS: Methanol: Toxicity, Regulation and Analysis. What is methanol? AGQ Labs Chile, 2018.

27. Behar RZ, Luo W, Lin SC, Wang Y, Valle J, Pankow JF and Talbot P: Distribution, quantification and toxicity of cinnamaldehyde in electronic cigarette refill fluids and aerosols. Tob Control 25 (Suppl 2): ii94-ii102, 2016.

28. Kosmider L, Sobczak A, Prokopowicz A, Kurek J, Zaciera M, Knysak J, Smith D and Goniewicz ML: Cherry-flavoured electronic cigarettes expose users to the inhalation irritant, benzaldehyde. Thorax 71: 376-377, 2016.

29. Irwin R; National Toxicology Program: NTP Toxicology and Carcinogenesis Studies of Furfural (CAS No. 98-01-1) in F344/N Rats and B6C3F1 Mice (Gavage Studies). Natl Toxicol Program Tech Rep Ser 382: 1-201, 1990.

30. Sleiman M, Logue JM, Montesinos VN, Russell ML, Litter MI, Gundel LA and Destaillats H: Emissions from electronic cigarettes: Key parameters affecting the release of harmful chemicals. Environ Sci Technol 50: 9644-9651, 2016.

31. Bekki K, Uchiyama S, Ohta K, Inaba Y, Nakagome H and Kunugita N: Carbonyl compounds generated from electronic cigarettes. Int J Environ Res Public Health 11: 11192-11200, 2014.

32. Hajek P, Etter JF, Benowitz N, Eissenberg T and McRobbie H: Electronic cigarettes: Review of use, content, safety, effects on smokers and potential for harm and benefit. Addiction 109: 1801-1810, 2014.

33. Hutzler C, Paschke M, Kruschinski S, Henkler F, Hahn J and Luch A: Chemical hazards present in liquids and vapors of electronic cigarettes. Arch Toxicol 88: 1295-1308, 2014.

34. Kim KH, Kabir E and Jahan SA: Review of electronic cigarettes as tobacco cigarette substitutes: Their potential human health impact. J Environ Sci Health Part C Environ Carcinog Ecotoxicol Rev 34: 262-275, 2016. 
35. Papoušek R, Pataj Z, Nováková P, Lemr K and Barták P: Determination of acrylamide and acrolein in smoke from tobacco and E-cigarettes. Chromatographia 77: 1145-1151, 2014.

36. Uchiyama S, Inaba Y and Kunugita N: Determination of acrolein and other carbonyls in cigarette smoke using coupled silica cartridges impregnated with hydroquinone and 2,4-dinitrophenylhydrazine. J Chromatogr A 1217: 4383-4388, 2010.

37. Geiss O, Bianchi I and Barrero-Moreno J: Correlation of volatile carbonyl yields emitted by e-cigarettes with the temperature of the heating coil and the perceived sensorial quality of the generated vapours. Int J Hyg Environ Health 219: 268-277, 2016.

38. Kosmider L, Sobczak A, Fik M, Knysak J, Zaciera M, Kurek J and Goniewicz ML: Carbonyl compounds in electronic cigarette vapors: Effects of nicotine solvent and battery output voltage. Nicotine Tob Res 16: 1319-1326, 2014

39. Cai $\mathrm{H}$ and Wang C: Graphical review: The redox dark side of e-cigarettes; exposure to oxidants and public health concerns. Redox Biol 13: 402-406, 2017.

40. Hoffmann D, Rivenson A, Murphy SE, Chung FL, Amin S and Hecht SS: Cigarette smoking and adenocarcinoma of the lung: the relevance of nicotine-derived $\mathrm{N}$-nitrosamines. J Smoking-Related Disord 4: 165-189, 1993.

41. Cheng T: Chemical evaluation of electronic cigarettes. Tob Control 23 (Suppl 2): iil1-ii17, 2014

42. Oh J-A and Shin H-S: Identification and quantification of several contaminated compounds in replacement liquids of electronic cigarettes by Gas chromatography-mass spectrometry. J Chromatogr Sci 53: 841-848, 2015.

43. Badia Tahull MB, Leiva Badosa E, Colls González M and Llop Talaverón J: Endocrine disruptors in artificial nutrition. Nutr Hosp 35: 469-473, 2018 (In Spanish).

44. Hess CA, Olmedo P, Navas-Acien A, Goessler W, Cohen JE and Rule AM: E-cigarettes as a source of toxic and potentially carcinogenic metals. Environ Res 152: 221-225, 2017.

45. Goniewicz ML, Knysak J, Gawron M, Kosmider L, Sobczak A Kurek J, Prokopowicz A, Jablonska-Czapla M, Rosik-Dulewska C, Havel C, et al: Levels of selected carcinogens and toxicants in vapour from electronic cigarettes. Tob Control 23: 133-139, 2014.

46. Mikheev VB, Brinkman MC, Granville CA, Gordon SM and Clark PI: Real-time measurement of electronic cigarette aerosol size distribution and metals content analysis. Nicotine Tob Res 18: 1895-1902, 2016.

47. Williams M,Bozhilov K, Ghai S and Talbot P: Elements including metals in the atomizer and aerosol of disposable electronic cigarettes and electronic hookahs. PLoS One 12: e0175430, 2017.

48. Carvajal C: Reactive oxygen species: training, function and oxidative stress. Med Leg Costa Rica 36: 91-100, 2019.

49. Lerner CA, Sundar IK, Yao H, Gerloff J, Ossip DJ, McIntosh S, Robinson R and Rahman I: Vapors produced by electronic cigarettes and e-juices with flavorings induce toxicity, oxidative stress, and inflammatory response in lung epithelial cells and in mouse lung. PLoS One 10: e0116732, 2015.

50. Park SJ, Walser TC, Perdomo C, Wang T, Pagano PC, Liclican EL, Krysan K, Larsen JE, Minna JD, Lenburg ME, et al: Abstract B16: The effect of e-cigarette exposure on airway epithelial cell gene expression and transformation. Clin Cancer Res 20 (Suppl 2): B16-B16, 2014.

51. Cressey D: E-cigarettes affect cells. Nature 508: 159, 2014

52. Ganapathy V, Manyanga J, Brame L, McGuire D, Sadhasivam B, Floyd E, Rubenstein DA, Ramachandran I, Wagener T and Queimado L: Electronic cigarette aerosols suppress cellular antioxidant defenses and induce significant oxidative DNA damage. PLoS One 12: e0177780, 2017

53. Tommasi S, Bates SE, Behar RZ, Talbot P and Besaratinia A: Limited mutagenicity of electronic cigarettes in mouse or human cells in vitro. Lung Cancer 112: 41-46, 2017.

54. Martin EM, Clapp PW, Rebuli ME, Pawlak EA, Glista-Baker E, Benowitz NL, Fry RC and Jaspers I: E-cigarette use results in suppression of immune and inflammatory-response genes in nasal epithelial cells similar to cigarette smoke. Am J Physiol Lung Cell Mol Physiol 311: L135-L144, 2016.

55. Chitu V and Stanley ER: Colony-stimulating factor-1 in immunity and inflammation. Curr Opin Immunol 18: 39-48, 2006.

56. Khan NA, Yogeswaran S, Wang Q, Muthumalage T, Sundar IK and Rahman I: Waterpipe smoke and e-cigarette vapor differentially affect circadian molecular clock gene expression in mouse lungs. PLoS One 14: e211645, 2019.
57. Lechasseur A, Jubinville É, Routhier J, Bérubé JC, Hamel-Auger M, Talbot M, Lamothe J, Aubin S, Paré MÈ, Beaulieu MJ, et al: Exposure to electronic cigarette vapors affects pulmonary and systemic expression of circadian molecular clock genes. Physiol Rep 5: e13440, 2017.

58. Caliri AW, Caceres A, Tommasi S and Besaratinia A: Hypomethylation of LINE-1 repeat elements and global loss of DNA hydroxymethylation in vapers and smokers. Epigenetics 15: 816-829, 2020

59. Solleti SK, Bhattacharya S, Ahmad A, Wang Q, Mereness J, Rangasamy T and Mariani TJ: MicroRNA expression profiling defines the impact of electronic cigarettes on human airway epithelial cells. Sci Rep 7: 1081, 2017.

60. Ganapathy V, Manyanga J, Brame L, McGuire D, Sadhasivam B, Floyd E, Rubenstein DA, Ramachandran I, Wagener T and Queimado L: Electronic cigarette aerosols suppress cellular antioxidant defenses and induce significant oxidative DNA damage. PLoS One 12: e0177780, 2017.

61. Chen H, Li G, Chan YL, Chapman DG, Sukjamnong S, Nguyen T, Annissa T, McGrath KC, Sharma P and Oliver BG: Maternal E-Cigarette Exposure in Mice Alters DNA Methylation and Lung Cytokine Expression in Offspring. Am J Respir Cell Mol Biol 58: 366-377, 2018.

62. Kennedy AE, Kandalam S, Olivares-Navarrete R and Dickinson AJG: E-cigarette aerosol exposure can cause craniofacial defects in Xenopus laevis embryos and mammalian neural crest cells. PLoS One 12: e0185729, 2017.

63. Allen JG, Flanigan SS, LeBlanc M, Vallarino J, MacNaughton P, Stewart JH and Christiani DC: Flavoring chemicals in e-cigarettes: Diacetyl, 2,3-pentanedione, and acetoin in a sample of 51 products, including fruit-, candy-, and cocktail-flavored e-cigarettes. Environ Health Perspect 124: 733-739, 2016.

64. Flouris AD, Chorti MS, Poulianiti KP, Jamurtas AZ, Kostikas K, Tzatzarakis MN, Wallace Hayes A, Tsatsakis AM and Koutedakis Y: Acute impact of active and passive electronic cigarette smoking on serum cotinine and lung function. Inhal Toxicol 25: 91-101, 2013.

65. Coppeta L, Magrini A, Pietroiusti A, Perrone S and Grana M: Effects of smoking electronic cigarettes on pulmonary function and environmental parameters. Open Public Health J 11: 360-368, 2018.

66. Ferrari M, Zanasi A, Nardi E, Morselli Labate AM, Ceriana P, Balestrino A, Pisani L, Corcione N and Nava S: Short-term effects of a nicotine-free e-cigarette compared to a traditional cigarette in smokers and non-smokers. BMC Pulm Med 15: 120, 2015.

67. Kerr DMI, Brooksbank KJM, Taylor RG, Pinel K, Rios FJ, Touyz RM and Delles C: Acute effects of electronic and tobacco cigarettes on vascular and respiratory function in healthy volunteers: A cross-over study. J Hypertens 37: 154-166, 2019.

68. Chaumont M, Tagliatti V, Channan EM, Colet JM, Bernard A, Morra S, Deprez G, Van Muylem A, Debbas N, Schaefer T, et al: Short halt in vaping modifies cardiorespiratory parameters and urine metabolome: A randomized trial. Am J Physiol Lung Cell Mol Physiol 318: L331-L344, 2020.

69. Antoniewicz L, Brynedal A, Hedman L, Lundbäck M and Bosson JA: Acute effects of electronic cigarette inhalation on the vasculature and the conducting airways. Cardiovasc Toxicol 19: 441-450, 2019.

70. Polosa R, Cibella F, Caponnetto P, Maglia M, Prosperini U, Russo C and Tashkin D: Health impact of E-cigarettes: A prospective 3.5-year study of regular daily users who have never smoked. Sci Rep 7: 13825, 2017.

71. Grigg J: E-cigarette regulation: Getting it wrong costs lives. Lancet Respir Med 7: 994-995, 2019.

72. Kennedy RD, Awopegba A, De León E and Cohen JE: Global approaches to regulating electronic cigarettes. Tob Control 26: 440-445, 2017.

73. World Health Organization (WHO): Parties to the WHO Framework Convention on Tobacco Control. WHO Framework Convention on Tobacco Control, 2020.

74. Institute for Global Tobacco Control: Country Laws Regulating E-cigarettes: A Policy Scan. Johns Hopkins Bloomberg School of Public Health, Baltimore, MD, 2020. https://www.globaltobaccocontrol.org/e-cigarette_policyscan. Last Updated May 18, 2020

75. World Health Organization (WHO): Electronic nicotine delivery systems: Report by WHO. Conference of the Parties to the WHO Framework Convention on Tobacco Control, Moscow, 2014 